\title{
A Comparative Study About Cost of the Pilgrimage Characteristics-Based Rupiah and Dinar (Survey on Pt. Bank Syariah Mandiri Branch Bandung and Dinar Tauhid Bandung)
}

\author{
Firmansyah $^{1}$
}

${ }^{1}$ Faculty of Economic and Business Education, Indonesia Education University, Bandung.

E-mail: firmans2020@yahoo.co.uk

\begin{abstract}
Haij is obligatory for Muslims who are able, physically, mentally, and materially. Trend of pilgrims making the Hajj pilgrimage from year to year increase. Due to capacity limitations in Mecca that makes every country of the quota number of people who can perform the pilgrimage every year. Because currencies are pilgrims Indonesia Rupiah (paper money not based on gold / fiat money), then the Hajj planning to use the money amount in at least two uncertainties, the factors of inflation and exchange rate factors (exchange rate). Because these two factors the cost of the pilgrimage $(\mathrm{ONH})$ has a tendency to increase every year, up from year to year. increases in the cost of the pilgrimage can be a very significant amount. To fulfill the ONH is one way to save money both in rupiah in PT. Bank Syariah Mandiri Branch Bandung or even saving dinar (4.25 grams of 22 carat gold) in Dinar Tauhid Bandung. This study aims to determine the operating system cost of the pilgrimage rupiah based in PT. Bank Syariah Mandiri, operating system cost of pilgrimage Dinar based in Dinar Tauhid Bandung, and the comparison of operating system-based cost of pilgrimage rupiah in PT. Bank Syariah Mandiri with dinar based in the Dinar Tauhid Bandung. Object of research is only one ONH, with different places, there are PT. Bank Syariah Mandiri branch of Bandung and Dinar Tauhid Bandung. In this study, use of comparative research methods. With the type of research is a qualitative study consisting of a definition of Haj savings and the savings contract is used, the mechanism of how to save money, and profit sharing. Primary data obtained from interviews with relevant parties, while the secondary data obtained from books, journals, internet and other literature.Based on the results of research that has been done shows that saving money dinar with the product more profitable m-dinar is free of ONH price inflation rise to an average of $11.21 \%$ per year, and the dinar appreciated on average toward the rupiah currency (fiat money) by $26,46 \%$ per year. Saving dinar get favorable share outcome.
\end{abstract}

Keywords: BSM mabrur saving, m-dinar, cost of the pilgrimage (ONH)

\section{A. INTRODUCTION}

Based on the development of Indonesian pilgrim, sum of pilgrim congregation from year to year are increasing. Here are presented the table reports the number of Indonesian pilgrim quota.

Table 1: Report about Sum of Pilgrim Congregation Quota in Indonesia

\begin{tabular}{|c|c|c|}
\hline No & Year & Sum of Pilgrim Congregation \\
\hline 1 & 2005 & 188.642 \\
\hline 2 & 2006 & 205.000 \\
\hline 3 & 2007 & 210.000 \\
\hline 4 & 2008 & 207.000 \\
\hline 5 & 2009 & 210.000 \\
\hline 6 & 2010 & 211.000 \\
\hline 7 & 2011 & 221.000 \\
\hline
\end{tabular}

Source: Directorate General of Hajj and Umrah Organizers, Republic of Indonesia (Februari 2012) 
Due to limited capacity in Mecca that makes any State in ration (quote) the number of people who can perform the pilgrimage every year. So if there is someone willing to perform the pilgrimage this year, not necessarily get the opportunity pilgrimage in the coming year, but it could be a new opportunity coming three to five years to come. Due pilgrimage opportunities are still some years to come, then how much money will be prepared so that when the opportunity came, funds pilgrim really enough, then this is where the problem is.

The main cost components pilgrimage is a foreign currency is U.S. dollars for plane tickets and Riyal currency for living expenses while in the holy land. Because currencies are pilgrims Indonesia Rupiah (not paper money based on gold / fiat money), then using the hajj planning Rupiah has at least two uncertainties, which factors in inflation and exchange factors (exchange rate/kurs).

Because of these two factors is the cost of the pilgrimage in Rupiah has a tendency to increase the amount go up from year to year. Moreover, in 2011, in which the Rupiah experiencing a sharp decline in the exchange rate against the U.S. dollar and the Riyal, Rupiah pilgrimage cost increases can be very significant. (Iqbal, 2011). These reports will be presented tables Indonesian Hajj Operation Costs.

Table 2: Indonesian Hajj Operation Costs

\begin{tabular}{|c|c|c|c|c|c|c|c|c|}
\hline No & Year & $\begin{array}{c}\text { Costs } \\
\text { (USA } \\
\$ \text { ) }\end{array}$ & $\begin{array}{c}\text { Costs } \\
\text { (Rp) }\end{array}$ & $\begin{array}{c}\text { Inflation } \\
\text { Rp } \\
(\%)\end{array}$ & $\begin{array}{l}\text { Price } \\
1 \text { Dinar } \\
\text { (Rp) }\end{array}$ & $\begin{array}{c}\text { Depreciation } \\
\text { Rp } \\
(\%)\end{array}$ & $\begin{array}{c}\text { Costs } \\
\text { (Dinar) }\end{array}$ & $\begin{array}{c}\text { Deflation } \\
\text { Dinar } \\
(\%)\end{array}$ \\
\hline (1) & (2) & (3) & (4) & (5) & (6) & (7) & (8) & (9) \\
\hline 1 & 2005 & 2.732 & 28.462 .948 & - & 551.077 & - & 51,6 & - \\
\hline 2 & 2006 & 2.852 & 25.921 .953 & $-8,92$ & 783.632 & 42,20 & 33 & 36,04 \\
\hline 3 & 2007 & 2.926 & 27.342 .536 & 5,48 & 1.090 .100 & 39,12 & 25 & 24,24 \\
\hline 4 & 2008 & 3.430 & 31.178 .700 & 14,03 & 1.212 .480 & 11,22 & 25,7 & $-2,8$ \\
\hline 5 & 2009 & 3.512 & 35.474 .712 & 13,77 & 1.418 .601 & 17 & 25 & 2,7 \\
\hline 6 & 2010 & 3.342 & 30.535 .854 & $-13,92$ & 1.659 .763 & 17 & 18,4 & 26,14 \\
\hline 7 & 2011 & 3.549 & 30.771 .900 & 0,77 & 2.294 .887 & 38,26 & 13,4 & 27,17 \\
\hline 8 & 2012 & & 33.276 .400 & & & & & \\
\hline \multicolumn{4}{|c|}{ Average } & 11,21 & & 26,46 & & 18,92 \\
\hline
\end{tabular}

Source: Developed for the research, 2012

Based on Table 2 above, it can be seen that the cost of the pilgrimage in rupiah (column 5 ) experienced price increases (inflation) average of $11,21 \%$ per year. Meanwhile, the cost of the pilgrimage $(\mathrm{ONH})$ when the dinar was experiencing falling prices (deflation) averaging $18,92 \%$ per year.

Based on Table 2 above, also it can be seen that the cost of organizing the pilgrimage/ fare pilgrimage $(\mathrm{ONH})$ if it refers to the amount of paper money standard (Rupiah) then an increase the fare pilgrimage $(\mathrm{ONH})$ even in 2012 rise to Rp. 33.276.400. The increase in $\mathrm{ONH}$ is based on decision of the Commission VIII House of Representatives and the Ministry of Religious Affairs Republik of Indonesia, the increase in $\mathrm{ONH}$ is called inflation. By contrast, if $\mathrm{ONH}$ refers to the standard dinars ( 1 dinar $=4.25$ grams of 22 carat gold) then the opposite is true, namely a decline in prices, and this is called deflation.

To meet the fare pilgrimage $(\mathrm{ONH})$, pilgrims can use the savings product pilgrimage mudharabah mutlaqah As we know, that could have gone to perform the pilgrimage, at least have to wait for three to five years, and during that time also, when pilgrims saving in the form of paper money (Rupiah) it is not protected from inflation (increase $\mathrm{ONH}$ ) each year, so we need an alternative way of saving endure toward inflation and a more profitable. 
Based on this background, it is necessary to conduct research to determine the ratio between the cost of pilgrimage $(\mathrm{ONH})$ characteristic based Rupiah and dinar.

The aims of this paper is trying to answer the following research questions:

1. How the operational system does cost pilgrimage rupiah based on PT. Bank Syariah Mandiri?

2. How does the operational system costs pilgrimage dinar based on Dinar Tauhid?

3. How does comparison of operating systems cost of pilgrimage rupiah based on PT. Bank Syariah Mandiri with the dinar based on Dinar Tauhid Bandung?

\section{B. METHODOLOGY}

\section{Methods Used}

This paper used comparative research methods. Comparative research is a method of research that is comparing. Here still the same object to different places more than one, or in a different time (Sugiyono, 2007:11).

Object under study is the one that is saving the cost of the pilgrimage $(\mathrm{ONH})$ to different places, namely PT. Bank Syariah Mandiri branch Bandung with Dinar Tauhid Bandung.

\section{Type of Research}

Type of research is a qualitative research consisting includes definitions hajj savings and savings contract is used, the mechanism of how to save money, and profit sharing.

Qualitative research is a study only describes the state of the object associated with the object under study are discussed in the study. This type of research is used to examine the condition of natural objects (as his opponent is an experiment), where the researcher is a key instrument (Sugiyono, 2006:9).

\section{Data Collection Techniques}

In this section argued that, in a qualitative study, primary data collection techniques were observation, in-depth interviews, document study, and the three combined or triangulation. It should be noted that the technique of collecting data by observation, it is worth noting what is observed, when interviewed, to whom will conduct the interview (Sugiyono, 2009:147).

\section{Data Sources}

Data is the raw material if processed through a series of analyzes can deliver a variety of information (Usman \& Purnomo, 2008:15). The data source of this research is the source of the data needed for the study. According Suharsimi Arikunto (2006:129) "The data source is the subject from which the data can be obtained." Based on the data source can be divided into two, namely primary data and secondary data. 


\begin{tabular}{|c|l|c|l|}
\hline \multicolumn{4}{|c|}{ Table 3: Data Sources } \\
\hline No & \multicolumn{1}{|c|}{ Data } & Data Source & \multicolumn{1}{c|}{ Description } \\
\hline \multirow{2}{*}{1} & $\begin{array}{l}\text { Operating system ONH rupiah } \\
\text { based }\end{array}$ & primary & $\begin{array}{l}\text { Interview to the Bank Syariah } \\
\text { Mandiri Bandung }\end{array}$ \\
\cline { 3 - 4 } 2 & $\begin{array}{l}\text { Operating system ONH dinar } \\
\text { based }\end{array}$ & secondary & $\begin{array}{l}\text { Books, journals, the internet and } \\
\text { other literature }\end{array}$ \\
\cline { 3 - 4 } & primary & $\begin{array}{l}\text { Interview to Sukmalinto owner Dinar } \\
\text { Tauhid Bandung }\end{array}$ \\
\hline \multirow{2}{*}{3} & $\begin{array}{l}\text { Comparison between the } \\
\text { ONH operating system rupiah } \\
\text { based with dinar based }\end{array}$ & secondary & $\begin{array}{l}\text { Books, journals, the internet and } \\
\text { other literature }\end{array}$ \\
\cline { 3 - 4 } & primary & $\begin{array}{l}\text { Interview to the Bank Syariah } \\
\text { Mandiri and owner Dinar Tauhid } \\
\text { Bandung }\end{array}$ \\
\hline
\end{tabular}

Source: Developed for the research, 2012

\section{RESULTS AND DISCUSSION}

\section{Literature Review}

The foundation of the theory is relevant theories used to explain the relationship objects studied, contained in the formulation of the problem (Sugiyono, 2007:305). These will be given of the theory about inflation, cost, money, operational savings hajj based rupiah and dinar, consumen behavior, and consumen protection.

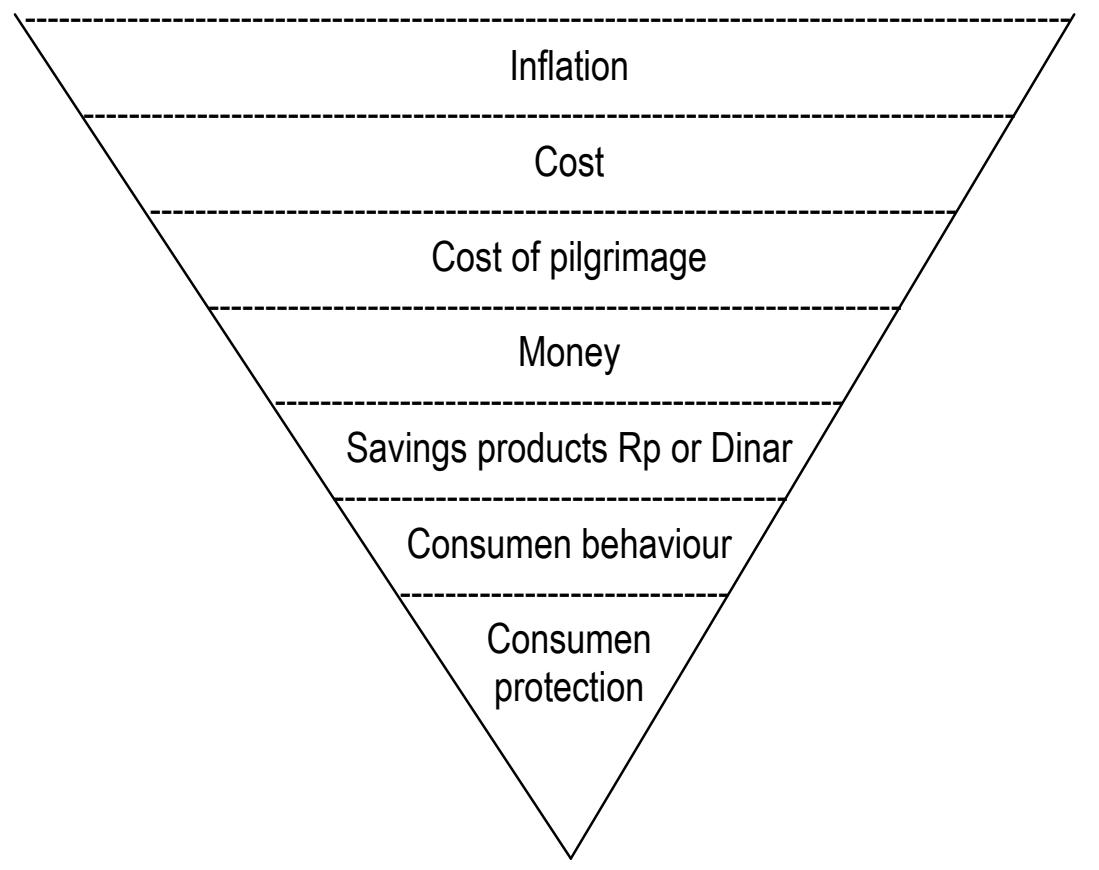

Description: Inflation drives up the cost of production of goods and services rise up (high cost production). Cost is the sacrifice of economic resources that already, be in the process and will occur for a specific purpose. Cost for the purpose of pilgrimage called $\mathrm{ONH}$ (ongkos naik haji)/BPIH (cost of organizing the pilgrimage) and $\mathrm{ONH}$ it will go up in line with rising production costs due to inflation. In fulfill the cost of the pilgrimage $(\mathrm{ONH})$ could use rupiah currency (fiat money) or dinar (full bodied money). To pay cost of the pilgrimage (ONH) by saving rupiah or dinars based. Selection of a goods or services in this case whether the consumer (pilgrims) prefer Hajj savings rupiah or dinar, it will be linked to consumen behavior. When the pilgrims had settled 
on a product or service in this case saving rupiah or dinars $\mathrm{ONH}$ types, it is necessary related to consumen protection for consumers (pilgrims) are not harmed.

\section{Inflation}

Basically, the inflation rate is used to describe the symptoms of the rise in the prices of goods and services within a certain time.

According to Al-Maqrizi, argued that: "Inflation occurs when prices are generally increasing and continuous. At this time, the supply of goods and services due to scarce and consumers really need to spend more money for a number of the same goods and services."

According Sadono Sukirno (2002:15) that: "Inflation is a rise in the prices prevailing in the economy."

According Manullang (1993:83) that: "Inflation is a situation where there is always falling currency values."

According Tajul Khalwaty (2000:5) that: "Inflation is a condition that indicates the weakening purchasing power, followed by a further decline in the real value (intrinsic currency of a country)."

Money in society become commonly accepted medium of exchange in which goods and services can be traded for cash (money). Money in itself can be shaped and made of various materials (ranging from precious metals to less valuable materials like paper / fiat money or plain metal). In the present intrinsic value (the value of the material used as money) is usually much smaller than the nominal value of money. As a result of the low intrinsic value of money that is the one of the causes of inflation (Karim, 2004:137). For example, paper money has a nominal Rp. 100,000, its intrinsic value is only Rp. 500 (Saifullah, 2009:56).

\section{Cost}

According to Mulyadi (2005:8), the cost is the sacrifice of economic resources is measured in units of money, which has happened, is happening or is likely to occur for a particular purpose.

There are costs associated with muamalah and worship. As we know that Hajj is included worship and a contract that is used to perform the pilgrimage is an akad/agreement tabarru. 'Akad tabarru' (contract goodness) is all kinds of agreements relating to non-for profit transaction (transaction nonprofit). The transaction is in fact not a business transaction for commercial profit. However, those who do good (in this case the government as the primary caretaker hajj) may request to his counter-part (pilgrims) to just cover the cost of that amount to be able to perform the pilgrimage (Karim, 2009:66).

The government of course requires the other stakeholder in this case, the airline Services Company, lodging, cattering, and so on. The company's position differs with the government where the government has position as public services while companies that did was set up to seek profit (akad/contract tijarah). To fulfill the cost of the pilgrimage $(\mathrm{ONH})$ could use rupiah currency (fiat money) or dinar (full bodied money). Therefore, it is important discussions related to the money that will be discussed below. 


\section{Money}

Estimated value of goods and services in any country represented by the units, the units that is the standard used to measure the usefulness of goods and labor / services. These units became a medium of exchange (medium of exchange). A unit is called by the name of money. Money is usability standards contained in the goods and labor. Therefore, money is defined as something that is used to measure each item and labor/ services. Suppose that price is the standard for the goods, while the wage is the standard for humans, each of which is an estimate of the value of the goods and the labor/ services of people (an-Nabhani, 2009:298).

Money is the value standard price measure, which is a medium measurer value commodities and services, and commodity price comparisons with other commodities. In a barter system, it is very difficult to know the price of a commodity at a price other commodities. And so it is with the price of a service to other services (Hasan, 2005:12)

Ibn al-Qayyim (d. $751 \mathrm{H}$ ) said:

"Dinar and dirham is the value of commodity prices. Price value is a measure that is known to measure the property shall be specific and accurate, does not rise nor decline. Because if the unit price value can rise and fall as commodity itself, of course, we no longer have the size to be validated to measure the value of commodities. In fact everything is a commodity."

He hinted that the money is the standard unit of measure for the value of commodity prices and presuppose money should have the strength and buying power are fixed in order to work properly is no inflation. You can imagine how the turmoil in the markets if the length of meter change without estimates from time to time, sometimes meter 150 centimeters long, sometimes 75 centimeters, then 90 centimeters. Certainly a lot of human affairs and their interaction would have chaos (Zaki Syafi'i, 1982:20).

As we know this chaos happens now when the type of money used is paper money (fiat money) that is not backing by gold, including rupiah as fiat money that have intrinsic value (the value of the material used as money) is smaller than its nominal value. As a result of the low intrinsic value of paper money that is the one of the causes of inflation (Karim, 2004:137).

The word Nuqu'd not found in the Qur'an and the hadith of the Prophet., Because the Arabs generally do not use the word nuqu'd to indicate the price. They use the word dinar to indicate currency made from gold (al-Kramly, 1987:30), dirham to show the means of exchange are made of silver (al-Naqsyabandi, 1969). They are also used word wariq to indicate silver dirham, the word 'Ain to show the gold dinar (al-Fayu'mi, 1926:262). As for the word fulus (copper coins) is the medium of exchange used to purchase additional bargains (Fari'd Wajdi, p. 403).

\section{Hajj Saving Based Rupiah}

According to Muhammad (2005:93) in the book Islamic Banking Management, development of Islamic banking products are grouped into three groups, namely:
a. Funding Product
b. Financing Product
c. Services Product 
Funding products, where there is mudharabah applied to savings deposits, the savings are meant for specific purposes, such as sacrificial savings and pilgrimage savings (Antonio, 2009:97)

Hajj Savings mudharabah, is the third party deposits in rupiah a withdrawal made at the time the customer will perform the pilgrimage, or in certain circumstances in accordance with the agreement with the customer is a savings earn rewards for results. In all types of savings mudaraba, a bank will share profits mudharib to shahibul ma'l according to an agreed ratio. Profit sharing can be done every month based on the minimum balance that settles over the period (Shomad, 2011).

\section{Hajj Saving Based Dinar}

The main cost components pilgrimage is foreign currency is the U.S. Dollar to Saudi Riyal plane ticket and living expenses while there. Because the currency in the country of Indonesia is Rupiah, planning pilgrimage use Rupiah has at least two uncertainties, which factors in inflation and exchange rate factors.

Because of these two factors is the cost of the pilgrimage we have a tendency to increase in amount from year to year. Moreover, the year when rupiah experienced a sharp decline in value against the U.S. Dollar and the Riyal, Rupiah pilgrimage cost increases can be very significant. Since Savings dinar (M-dinar) uses the concept Mudharabah, Dinar savers do not charge any deposit or fee. Even after the Dinar will actually physically rotating fund the real sector of the economy, savers M-Dinar will get the results in the form of Dinar (Iqbal, 2012).

Here is an example of saving dinars, in January we save Rp. 750.000 (eg dinar at that price Rp. 1.5 million), the balance is $0.5 \mathrm{~m}$-dinar dinar. In February when saving again Rp. 400.000 (dinars price of Rp. 1.6 million), savings increased $0.25 \mathrm{~m}$-dinar dinar. Saving again in March if Rp. 560.000 (dinars price of Rp. 1.6 million), savings increased 0.35 m-dinar dinar. So the total is 1.1 dinars.
a. January - Rp. $750.000 / 1.500 .000-0.5$ dinar
b. February - Rp. 400.000/1.600.000 - 0.25 dinars
c. March - Rp. 560.000/1.600.000 - 0.35 dinars
d. Total -1.1 dinars (physical dinar can be taken / sent)

\section{Consumen Behaviour}

Schiffman and Kanuk, as quoted by Sonny Sumarwan define consumer behavior is the behavior shown consumers in finding, purchasing, using, evaluating, and spent products and services that they expect will satisfy their needs (Sumarwan, 2004:25).

There are three factors that influence consumer choice. The first factor is the individual consumer. The second factor is the environment that affects consumers, such as culture, social class, reference groups and situational factors. The third factor is the marketing strategy. (Sutisna, 2003:6-7).

Factors that may influence individual differences consist of the purchase decision; needs and motivations, personality, information processing and perception, learning, knowledge, and attitudes. (Sumarwan, 2004:31). 
Knowledge pilgrims about the resilience dinars (full bodied money) and the vulnerability of paper money (fiat money) on inflation is one factor that can help pilgrims to choose what kind of money and how to save $\mathrm{ONH}$ protect the value of their money is safe and profitable.

\section{Consumen Protection}

According to Az. Nasution (2002:22) is the overall understanding of consumer law principles and rules governing the relations and the problem of providing and using products (goods and / or services) between providers and users, in social life. According to him, consumer protection law is part of consumer law. Consumer protection law itself has an overall definition of the principles and rules that govern and protect consumers in relation to the issue of the provision and use of products (goods and / or services) between the provider and its use in society (Nasution, 2002:20-21).

It therefore meant that consumers (pilgrims) can obtain optimum results for the protection and / or legal certainty for his service-related pilgrimage starting from departure, while in the holy land, to return again to their homeland.

\section{a. Comparison Hajj savings and Used Akad/Agreement between Rupiah Based with Dinar Based}

Table 4: Comparison of Definitions, Akad And Purpose And Fatwa DSN between

\begin{tabular}{|c|c|c|c|}
\hline \multicolumn{2}{|c|}{ Hajj Savings Rupiah Based with Dinar Based } \\
\hline No & Comparator & Hajj Savings Rupiah Based & Hajj Savings Dinar Based \\
\hline 1 & Definition & $\begin{array}{c}\text { Mabrur Savings BSM is deposits } \\
\text { denominated in rupiah aimed at } \\
\text { helping the Muslim community in } \\
\text { planning for Hajj \& Umrah }\end{array}$ & $\begin{array}{c}\text { Hajj Savings dinar based (m- } \\
\text { dinar) is a savings dinars (22 } \\
\text { carat gold) to fulfill the cost of } \\
\text { the pilgrimage (ONH) }\end{array}$ \\
\hline 2 & Akad & Mudharabah Muthlaqah & Mudharabah Muthlaqah \\
\hline 3 & Purpose & $\begin{array}{c}\text { To fulfill cost of the pilgrimage } \\
\text { (ONH), investment fund } \\
\text { pilgrimage (get profit sharing) }\end{array}$ & $\begin{array}{c}\text { Asset value protection and } \\
\text { investment fund pilgrimage (get } \\
\text { profit sharing) }\end{array}$ \\
\hline 4 & FATWA DSN & $\begin{array}{c}\text { Appropriate with DSN MUI Fatwa } \\
\text { No. 02/DSN-MUI//V/2000 about } \\
\text { savings }\end{array}$ & $\begin{array}{c}\text { Appropriate with DSN MUI } \\
\text { Fatwa No. 02/DSN-MUI//V/2000 } \\
\text { about savings }\end{array}$ \\
\hline
\end{tabular}

Source: in-depth interviews with Rita Setiawan (Bank Syariah Mandiri Bandung, Mei 2012); and Sukmalito (owner Dinar Tauhid Bandung, juni 2012).

\section{b. Definition and Contract (Akad)}

From Table 4 above it can be seen, that there is no significant difference in terms of the definition, but there are significant differences in terms of the object that saving there are rupiah (paper money / fiat money) and dinar (full bodied money). In case there is a contract in which both types of savings equation either rupiah or dinar equally on the principle of Mudaraba Muthlaqah. Both BSM savings Mabrur or dinar savings, they both meet mudharabah harmony.

Mudaraba mutlaqah is a type of mudharaba, which there is no restriction for Islamic financial institutions in the use of funds raised. Savers did not give any conditions to the BLM, to what business was about to deposit funds rolled, or specify the use of contract-specific contract, or require the funds earmarked for specific customers. So Islamic financial institutions have complete freedom to distribute/roll savers to fund any business that is expected to benefit and of course halal (Karim, 2009:109). 
Pillars mudharaba perfectly fulfilled (Karim, 2009:108):

1) There mudharib (manager)

2) There shahibul ma'l (owner funds)

3) There is business to be been distributed

4) There is a ratio of profit

5) There is ijab qabul

\section{c. Purpose}

The purpose of these two types of savings are different, savings Hajj rupiah based just to fund the preparation of Hajj (pilgrimage fund investment) that does not rule out the possibility of funds invested pilgrims were prepared and the results will be affected by inflation (purchasing power rupiah fell against the $\mathrm{ONH}, \mathrm{ONH}$ prices rise). While m-dinar savings than pilgrimage fund investment aimed, also aims to protect the value of assets from inflation, because as we know the Islamic dinar is the currency of the face value of 1 dinarnya equal to its intrinsic value (real value) of material currency is 4.25 grams 22 carat gold. Money that has intrinsic value corresponding to the nominal value of its currency will be stable power for goods and services in other words more inflation resistant. Conversely, if the money intrinsic value is not in accordance with of the nominal value of money then the power exchange rate is not stable toward goods and services (inflation susceptible).

The intrinsic value of money serves as a hedge for them selves from inflation (Hamidi, 2007:162). So the value of the dinar is stable and has strong purchasing power toward $\mathrm{ONH}$.

As revealed by Muhammad Shafi'i and Ahmad Zaki Hasan, You can imagine how the turmoil in the markets if the length of meter change without estimates from time to time, sometimes long of the meter 150 centimeters, sometimes 75 centimeters, then 90 centimeters. Certainly a lot of human affairs and their interaction would have chaos (Syafi'i, 1982:20). In fact that's what happened in the interaction between humans after the adoption of paper money (fiat money) that does not have fixed the power exchange so at risk of developing various conditions of inflation (Hasan, 2005:14).

\section{d. Compliance with the Fatwa DSN}

While related to the suitability of DSN MUI fatwa No. 02/DSN-MUI/IV/2000 about savings, two types of savings (rupiah based and dinar based) has complied with the savings general provisions of the fatwa is based Mudharabah:

1. In this transaction the customer acts as shahibul ma'l or the owner of the funds, and bank/ financial institution as mudharib or act as a fund manager.

2. In his capacity as mudharib, banks can perform a variety of businesses that do not conflict with the principles of Shariah and develop, including mudharabah with others.

3. Capital must be stated with the amount, in cash, not credit.

4. Profit sharing ratio should be expressed in the form set forth in the contract and account opening

5. Bank/financial institution are not allowed to reduce the ratio of profit sharing without the customer's consent.

From the description that has been stated above (Comparison Hajj savings and Used Akad/Agreement between Rupiah Based with Dinar Based), it can be seen that there are 
similarities in terms of mudharabah muthlaqah and suitability to the provisions of DSN MUI fatwa No. 02 / DSN-MUI/IV/2000 about savings.

There are differences in the definition of savings in terms of hajj savings rupiah and dinar, with a note on the object savings the fund, if the fund Mabrur savings BSM object savings is rupiah (paper money/flat money), while the m-dinar object savings is dinar (full bodied money). Differences also occur in terms of purpose, if the savings base Hajj rupiah just to fund investments Haij (get profit sharing), while the hajj savings dinar base aims to protect the value of assets from inflation, and for investment funds haij (get profit sharing).

\section{e. Comparison about Saving Mechanism between Savings Hajj Rupiah Based And Dinar Based}

Table 5: Comparison about saving Mechanism between Savings Hajj Rupiah Based and Dinar Based

\begin{tabular}{|c|c|c|c|}
\hline No & Comparator & $\begin{array}{c}\text { Hajj Savings Rupiah } \\
\text { Based }\end{array}$ & Hajj Savings Dinar Based \\
\hline 1 & Open an account & $\begin{array}{l}\text { Easy, prospective clients } \\
\text { come to the office of Bank } \\
\text { Syariah Mandiri }\end{array}$ & $\begin{array}{l}\text { Quite complicated, because } \\
\text { the registration via internet }\end{array}$ \\
\hline 2 & $\begin{array}{l}\text { Administration costs } \\
\text { account opening }\end{array}$ & No & Rp. 20.000,- \\
\hline 3 & initial deposit & $\begin{array}{c}\text { Minimal Rp. } 500,000 \text {, further } \\
\text { deposit of at least Rp. } 100 \\
000\end{array}$ & $\begin{array}{l}\text { Minimum of } 0.25 \text { dinars (or } \\
25 \%{ }^{*} \text { kurs selling dinar), the } \\
\text { next deposit at least } 0.1 \\
\text { dinar. }\end{array}$ \\
\hline 4 & $\begin{array}{l}\text { Disbursements / } \\
\text { withdrawal of savings }\end{array}$ & $\begin{array}{l}\text { Can not withdrawal except } \\
\text { for paying cost of pilgrimage } \\
(\mathrm{ONH})\end{array}$ & $\begin{array}{c}\text { Can be drawn in the form of } \\
\text { rupiah or if in dinar least } 1 \\
\text { dinar. }\end{array}$ \\
\hline 5 & Deposit Insurance Agency & guaranteed & Not guaranteed \\
\hline 6 & Monthly administration fee & No & No \\
\hline 7 & $\begin{array}{l}\text { Closing costs account for } \\
\text { canceled Hajj }\end{array}$ & Rp. 25.000,- & No \\
\hline 8 & $\begin{array}{l}\text { Registration through an } \\
\text { integrated computerized } \\
\text { system (Siskohat) }\end{array}$ & Online & Not Online \\
\hline
\end{tabular}

(owner Dinar Tauhid Bandung, juni 2012).

\section{1) Open an Account and Initial Deposit}

Opening a savings account Mabrur BSM is easy, here is the short opening stage BSM Mabrur savings:

1. Prospective customers come directly to the office nearest BSM with a valid identity card (ID Card/Driving License/Passport).

2. Fill out the application form Mabrur opening a savings account.

3. Perform initial cash deposit of at least Rp. 500.000, -. Subsequent deposit of at least Rp. 100.000, -

4. Administrative costs account opening free.

Proof of ownership savings m-dinar is account number m-dinar and will also be able to book mdinar savings. These are opening stages of $m$-dinar savings:

1. Log into the site www.m-dinar.com please choose full web or direct access to www.mdinar.com/indo 
2. REGISTRATION Click on the menu on the left

3. Fill in name, username, email and password according to our choice

4. Then came the sentence "Your account has been created and an activation link has been sent to the e-mail address you entered. Note that you must activate the account by clicking on the activation link when you get the e-mail before you can login." Then we click on the link that has been sent to email us

5. Then back to www.m-dinar.com/indo then login with your User ID and Password that we have, and then click Mobile Payment

6. Fill data include the number of identity (ID card, driving license or Passport), full address corresponding identity, phone number and home phone number, and gender.

7. After that send data include User ID, no. ID and no. HP, the HP linto@dinartauhid.com or 087824030036 or YM: sceleton65. We will do the activation process

8. After the activation confirmation from us, please do transfer to our BCA account (please contact us for account number) of at least 0.25 dinars as an initial deposit (eg Rp 525,000 for selling the dinar exchange rate of January 2011, U.S. \$ 2.1 million * 0, 25). Deposit a minimum of 0.1 dinars next.

9. Insha Allah M-Dinar account you'll immediately be used by https://m-dinar.com/indo (login>> click mobile payment).

10. Administrative costs account opening m-dinar is Rp 20.000,- (payable in conjunction with the initial balance transfer) that one of them will be used for delivery of documents to the customer m-dinar.

11. The process of handling passbooks less than two weeks.

\section{2) Withdrawal, Closure and Administrative Closure Cost Savings}

BSM Mabrur savings cannot be liquidated except to pay off the cost of pilgrimage. Withdrawals can only be done in the "Emergency" and can only be done with a savings withdrawal slip and passbook shows and identity cards, then closing the account administration fee of Rp. 25,000 to cancel departures pilgrims (Setiawan, interview, 2012).

According Wiroso (2005:46-47), saving the mudaraba principle cannot be withdrawn at any time, then the savings by using this principle need not be given an ATM card. In its application of Islamic banking products using this principle, among others, Hajj Savings can be withdrawn only when the depositor will perform the pilgrimage, Qurban savings can only be withdrawn during the holidays qurban (savers buy animals qurban), Education Savings can be withdrawn only when savers paid education, walimah savings can be withdrawn only when the depositor will perform the marriage ceremony.

According to the Sukmalinto (interview, 2012) purpose of saving dinar is not for speculation. However, it should to protect the value of assets and investments to get profit sharing. The main principle if the customer has more rupiah can saving dinar, if customers need money so can be withdrawn. Here are guidelines for how to withdraw m-dinar savings:

1. The customer should notify one month before the date of disbursement / withdrawal. Withdrawals can be in the form of dollars or dinars.

2. When you will exchange your dinars to the dollar, our system will automatically calculate based on the current exchange rate Buy your transaction will be executed. You will be notified automatically what the purchase price and how much amount you will receive. 
-For example, on 5 June 20121 dinar selling price of Rp. 2.191.897 to Rp. 2.104.221, while purchasing Exchange. Suppose the customer has 2 dinars in his account, and the customer wants to melt in rupiah at Rp. 2.000.000,- then the calculation; 2 dinar* $2.104 .221=4.208 .442-2.000 .000$ = remaining Rp. 2.208.442/2.104.221 = 1.049 dinar (this is the last balance after being pulled).

1. Conversely, when the customer wants to withdraw or dilute in the form of dinar, the withdrawals can only be made with a minimum of 1 dinar and multiples thereof.

2. If you want to close the account of m-dinar, then you can directly go to the official agent Dinar nearest outlet, and no closing cost savings account.

\section{3) Deposit Insurance Agency}

Related to the Deposit Insurance Agency (DIA), the money deposited in Bank Syariah Mandiri it is guaranteed DIA, because BSM is a bank under the control of the central bank (Bank Indonesia).

While saving money on m-dinar is not guaranteed DIA, because of the legal entity or outlet Dinar is BMT Islamic Cooperative not bank institution. M-Dinar is not guaranteed DIA under the control of Bank Indonesia, but our AMANAH \& MORALITY beyond anything quite so ground for muamalah. So the track record of service M-Dinar was honest and trustworthy enough for customers to believe. Thousands of customers over the years, both inside and outside the country. Customer data is also recorded in full in the contract at the beginning.

\section{4) Monthly Administration Fee}

Free monthly administration fee for BSM Mabrur savings, while the m-dinar savings, because it uses the concept of m-Mudharabah dinar, dinar savers do not charge any deposit or fee. Even after the Dinar will actually rotate through the sale of dinar coin, savers M-dinar will get profit sharing in the form of dinar.

\section{5) Registration through an Integrated Computerized System (Siskohat)}

Bank Syariah Mandiri online to SISKOHAT (integrated computerized system) Ministry of Religious Affairs Republik of Indonesia since become one of the Beneficiary Bank Deposit ONH (Bank Penerima Setoran $\mathrm{ONH}$ ), which has been determined by the Ministry of Religious Affairs. Meanwhile, Gerai Dinar through the agency official Dinar Tauhid, Dinar Tauhid was not online to SISKOHAT because it is not Beneficiary Bank Deposit ONH, in fact it can be anticipated if dinar fulfill $\mathrm{ONH}$, the dinar customers can be withdrawn and converted into rupiah, and then get paid to travel Hajj or can also be directly paid to one of the Beneficiary Bank Deposit.

Role of Bank Syariah Mandiri with product BSM Mabrur savings are only to facilitate the registration and settlement cost of pilgrimage to SISKOHAT. More related to practice the rituals of Hajj, return preparation for departure to pilgrims, all of it is the duty Ministry of Religious Affairs Republik of Indonesia in collaboration with the pilgrimage travel (Setiawan, Interview, 2012).

6) Comparison of Benefits Share Outcome between Hajj Savings Rupiah Based and Dinar Based

Table 6: Comparison of Benefits Share Outcome between Hajj Savings Rupiah Based and Dinar Based

\begin{tabular}{|c|c|c|c|}
\hline No & Comparator & Hajj Savings Rupiah Based & Hajj Savings Dinar Based \\
\hline 1 & Type sharing system & Revenue sharing system & Profit sharing system \\
\hline 2 & Ratio Sharing & $25 \%$ for customers : $75 \%$ for banks & $50 \%$ customers : $50 \%$ \\
\hline
\end{tabular}




\begin{tabular}{|c|c|c|c|}
\hline & & & Gerai Dinar/Dinar Tauhid \\
\hline 3 & Technical calculations & $\begin{array}{c}\text { Not complicated, using computer } \\
\text { applications }\end{array}$ & $\begin{array}{c}\text { Not complicated, using } \\
\text { computer applications }\end{array}$ \\
\hline 4 & $\begin{array}{c}\text { Share outcome can } \\
\text { cover the annual } \\
\text { inflation rate. }\end{array}$ & $\begin{array}{c}\text { Unable to cover the average } \\
\text { annual inflation rate (the average } \\
\text { annual price increases ONH }\end{array}$ & $\begin{array}{c}\text { Able to cover the rising } \\
\text { price inflation ONH }\end{array}$ \\
\hline
\end{tabular}

Source: Developed for the research, 2012

\section{a. Sharing Type}

Meaning of mudharabah in raising funds to put shahibul ma"l or client depositor as the first, while mudharib or Islamic Bank as the second party as the manager of the fund. Thus it is an agreement of cooperation between the first party and second party in the management of wealth by dividing profits (profit sharing) in accordance with the agreements set forth in the contract (Hakim, 2011:216). Sharing system used by Bank Syariah Mandiri is revenue sharing system.

Fatwa National Sharia Council of in the number 15/DSN-MUI/IX/2000 dated 16 September 2000 on the principle of distribution of net income (profit sharing), as follows:

1. Basically, the Islamic Financial Institutions may use the principle of sharing / revenue (revenue sharing) as well as for profit (profit sharing) in the distribution of the results of operations with its partners (customers) it.

2. In terms of welfare (al ashlah), the distribution of the results of operations should be used in principle to yield / revenue (revenue sharing).

3. Determination of the principle of distribution of selected results of operations should be agreed in the contract.

Sharia banking system introduced to the community in terms of Revenue Sharing, the system of profit sharing is calculated from the total income without deducting fund management fund management costs (National Sharia Council, 2001:87). Revenue sharing more details in terms of banking is based on the results of the calculation for the total of all income received before deducting the related expenses incurred to earn that income. Revenue sharing system applies to bank earnings will be distributed is calculated based on gross revenues (gross sales), which is used in calculating the results for bank financing products (Tim Pengembangan Perbankan Syariah Institut Bankir Indonesia, Konsep, Produk, p. 264)

Profit sharing is based on the results of the calculation for net proceeds of the total income after deducting the expenses incurred to earn that income. The benefits of these efforts will be the division after the first calculation of the costs incurred during the business process. Business profits in the business world can be negative, it means loss of business, more positive meaning there figures the rest of the revenue minus costs, and zero meaning between revenues and expenses into balance. Profits are distributed net profit (net profit), which is the remainder of the difference in total cost reduction of the total revenue. Dinar Tauhid uses Profit Sharing system (Fallah, 2003).

\section{b. Technical Calculations}

Technical calculations share results/ outcome in BSM savings Mabrur:

1. Savers will get the results in accordance with kesepakaan made between the Bank and Savers. BSM savings ratio Mabrur non-bailouts pilgrimage was $25: 75,25 \%$ to customers and $75 \%$ of BSM. 
2. The tax on the profits earned by savers savers incurred in accordance with applicable regulations.

3. For the final results will be calculated each month and will be added to the savings account depositors at the beginning of next month.

Calculation of Bank Syariah Mandiri Bank calculations using computer applications:

\begin{tabular}{|c|c|}
\hline Average balance of customer Mr. A & Rp. 31.000 .000 \\
\hline Porsi Nisbah Nasabah & $25 \%$ \\
\hline Portion Customer Ratio & $75 \%$ \\
\hline Average balance of all customers in a month BSM & Rp. 40.000 .000 .000 \\
\hline Bank income that has been distributed to customers savings & Rp. 2.000 .000 .000 \\
\hline The number of day placements & 30 days \\
\hline Results obtained customer (before taxes) & Rp. 31.000 \\
\hline
\end{tabular}

Seen from the above calculations, that if the average balance of customer Mr. A in July of Rp. 31 million (rounding of prices $\mathrm{ONH}$ in 2011 of Rp. 30.771.900), with a ratio of $25 \%$ to customers and $75 \%$ for BSM. While the average balance of all customers Mabrur BSM savings in a particular month is Rp. 40 billion and the Bank's income that has been distributed to customers the savings is Rp. 2 billion to the days of the placement of 30 days, for customers results obtained is Rp. 31.000. If the annual average equal to Rp. 372.000 (Rp. 31.000* 12 months).

As we know that if someone has enough money to pay off the $\mathrm{ONH}$ is not necessarily pilgrimage that year, having to queue for the limited quota. Especially for customers who still have not paid off and keep saving until it is paid off $\mathrm{ONH}$ can be up to five (5) years customer was waiting. While the money owned by the customer and saved in the form of paper money (fiat money) are prone to inflation with an average annual inflation rate was $11.21 \%$ per year (Table 2: Indonesian Hajj Operation Costs). Then it can be calculated whether the result of saving the paper money to cover the annual inflation rate, the following calculation.

$\mathrm{ONH}$ inflation or rising prices raised an average of $11.21 \% /$ year. Price $\mathrm{ONH}$ in $2011=\mathrm{Rp}$. 30.771.900. What price $\mathrm{ONH}$ five years from now?

1. The formula $F V=P V *(1+r)^{n}$

2. $\mathrm{FV}=30,771,900 *(1+0.1121)^{5}=52,344,800$

3. So in the next five years in 2016 , assuming $11.21 \%$ rise per year $(r=0.1121)$, estimated the cost of the pilgrimage in 2016 was Rp.52.344.800. Rp. $52.344 .800-R p .30 .711 .900=R p .21 .632 .900: 5$ year $=$ Rp. 4.326 .580 per year. So $\mathrm{ONH}$ prices raise an average of Rp. 4.326 .580 per year. As for the revenue sharing of BSM savings Mabrur year is Rp. 372,000 .

Of course this can be compared and can also be known, and it can be concluded that the revenue sharing of the paper money to save money in a savings BSM Mabrur Rp. 372.000/tahun not cover the amount of the annual inflation rate, the rising price of $\mathrm{ONH}$ an average of Rp. 4.326.580/tahun. (prediction).

Calculation of the profit sharing (contract qirad) in Dinar Tauhid as official agent of Gerai Dinar, the following illustration:

1. Savers invest one dinar with contract qirad

2. Each 1 Dinar you successfully sold by outlets Dinar to the public, you immediately proceeds Dinar (in Rupiah) buy dinars back to Precious Metals by Gerai Dinar, so that your capital is always awake in the dinar value form. 
3. Due to the large volume of dinar to purchase Outlets Precious Metals, then 1 Dinar yours to enjoy the difference in the purchase price of the Precious Metals front Dinar.

4. All proceeds to the community you 1 Dinar earned dollar, and then bought back into precious metals (gold/LM), so that 1 dinar printed again and is now become 2 dinars.

5. From each extra 1 Dinar of the LM, when sold to the public should not be higher than $5 \%$ over the cost of LM. That is $5 \%$ ( 0.05 dinars) this is gross income so should we spend to $2 \%$ of net tax (0.02 dinars), for front Dinar support (administration, management, and services), which is 1\% (0.01 dinars). Mean net profit 0.02 dinars. Profit Sharing System.

6. Profit ratio 50\%: 50\%, then you as shahibulmal get 0.01 dinars and Sellers (Dinar Tauhid as an authorized agent of Gerai Dinar) also gained 0.01 dinars.

7. The assumption we can sell back 2 weeks after we receive your dinars back from LM (Logam Mulia) also takes about 2 weeks to make; then theoretically your capital will rotate approximately once a month.

8. If we successfully sold 1 times in one month, then your capital in the last 12 months has been the 1 Dinar $+0.01 * 12=1.12$ Dinar

9. Or when taken safety we only managed to sell / spin once in 2 months, then you become the Dinar 1 Dinar $+0.01 * 6=1.06$ Dinar

10. The figures are not meant to be predictive binding, as it would be riba if we promised figure certain.

Now, to be counted, whether the result of m-dinar savings will be able to cover (to cover) annual rate of inflation is rising prices $\mathrm{ONH}$ average Rp 4.326.580 per year, the following calculation:

1. In $2011 \mathrm{ONH}$ price $=13.4$ dinars. And customers keep in m-dinar.

2. 13.4 Dinar dinar make contract qirad in Dinar Tauhid as the authorized agent of Gerai Dinar

3. Each 1 dinar which successfully sold the net profit gained 0.02 dinar, and divided by the ratio 50\%: 50\%, means for customers to obtain 0.01 dinar.

4. If we successfully sold 1 time in a month that is selling 1 dinar, then the customers get 0.01 dinar / month.

5. That if the first month managed to sell 13 dinars (rounding down), so $13 * 0.01$ dinar $=$ 0.13 dinar dinars / month

6. If a year means $0.13 * 12=1.56$ dinar dinars.

7. Was then multiplied by 1.56 dinar 5 years (since leaving his Hajj predicted 5 years more than in 2011). $1.56 * 5=7.8$ dinar dinars.

8. Is then 7.8 dinar multiplied by dinar prices Rp.7.422.472 predicted in 2016. $=7.8{ }^{*} \mathrm{Rp}$. 7.422.472 = Rp. 57.895 .300 (that's predictions for the proit sharing of the year 2016).

9. To determine the annual revenue Rp. $57.895 .300: 5$ years $=$ average profit sharing is $R p$. 11.579 .000 per year.

10. In conclusion, average of profit sharing m-dinar Rp 11.579.000/tahun was able to cover annual rate of inflation is rising prices $\mathrm{ONH}$ average Rp 4.326.580/tahun. (prediction).

11. In fact when the dinar was 13.4 dinar in 2011 just saved not make contract qirad, then price of dinar automatically can rise, because the dinar has real intrinsic value ( 4.25 grams of 22 carat gold), then five years from the year 2016, the dinar to appreciate toward rupiah on average $26.46 \%$. With the price of 1 dinar prediction in 2016 is Rp. 7,422,472, the value of the dinar 13.4 in 2016 is $\mathrm{Rp} .99 .461 .100$ (prediction), the original value of 13.4 dinars in 2011 is Rp. 30.753 .000$.

This is called by the appreciation of the dinar toward the rupiah, which means that the exchange rate of the dinar against the strengthening of the rupiah. Appreciation is the strengthening of the 
exchange rate, while depreciation is declining exchange rate. It was clear from the above calculations that the rupiah to depreciate toward the dinar.

From the description that has been stated above (in the context of comparative advantage for the result of savings base Hajj pilgrimage savings dollars with dinars basis), it can be seen that there is equality in a way that is both less complex in terms of the calculation of the results, because both using the help of computer applications calculation.

There is a difference of three terms. Among them are: (1) In terms of the type of profit sharing basis hajj savings dollars using the type system of revenue sharing while the dinar basis using the type system of profit sharing (for profit). (2) In terms of the profit sharing ratio, savings pilgrimage rupiah base portion is $25 \%$ for customer savers and $75 \%$ for Bank Syariah Mandiri while the dinar base portion is $50 \%$ to customers and $50 \%$ for savers Dinar Tauhid. (3) In terms of the results in terms of whether or not to cover the annual inflation rate $\mathrm{ONH}$ prices, profit-sharing basis hajj savings dollars can not cover the average annual inflation rate (the average annual price increases $\mathrm{ONH}$ ) is only Rp 372,000 / year while the annual inflation rate rising average price of Rp 4.326.580/year $\mathrm{ONH}$. As for the results of dinar savings average basis for the result is Rp $11.579 .000 /$ tahun (prediction), this amount can cover the annual inflation rate rising average price of Rp 4.326.580/tahun ONH (prediction).

\section{CONCLUSION}

Operational system costs pilgrimage (Hajj) rupiah based on PT. Bank Syariah Mandiri can be explained in aspects / characteristics-based definition hajj savings rupiah, contract, and saving and sharing; a) Savings based Hajj rupiah in PT. Bank Syariah Mandiri is called by the name of saving Mabrur BSM products, namely deposits denominated in rupiah aimed at helping the Muslim community in planning for Hajj and Umrah. b) Agreement used in BSM is mudaraba mutlaqah Mabrur savings. c) How to save money very easily, prospective clients come to the office of Bank Syariah Mandiri closest to carry identity cards. Then the bank officer will later guide the savings associated with Mabrur. d) ratio for the results BSM Mabrur savings are $25 \%$ for the customers and $75 \%$ for Bank Syariah Mandiri bank revenues (revenue sharing). e) For the results of BSM Mabrur savings cannot cover the average annual inflation rate (the average annual price increases $\mathrm{ONH})$.

Operational system costs pilgrimage (Hajj) dinar based on Dinar Tauhid Bandung can be explained in aspects/characteristics-based definition hajj savings rupiah, contract, and how to save money and profit sharing; a) Savings based Hajj Dinar rupiah in Bandung called by the name of $\mathrm{m}$ dinar (dinars saving), the dinar savings (22 carat gold) addressed one of them to meet the cost of the pilgrimage (Haij). b) Agreement used in BSM is mudaraba mutlaqah Mabrur savings. c) How to save quite difficult, especially for people who are not accustomed to using the Internet, since the opening of accounts using the Internet. d) Profit-sharing ratio m-dinar was 50\% for the customers and $50 \%$ for Dinar Dinar Tahuhid as an authorized agent outlet of the net profits (profit sharing). e) For the results of m-dinar can cover the average annual inflation rate (the average annual price increases $\mathrm{ONH}$ ).

Comparison operational system costs pilgrimage (Hajj) rupiah based on PT. Bank Syariah Mandiri with the dinar based on Dinar Tauhid Bandung can be explained in terms of the similarities and differences; a) Both of them have a common aspect to meet the goal of saving the cost of the pilgrimage, mudharabah mutlaqah, corresponding DSN MUI fatwa No. 02/DSN-MUI/IV/2000 about savings, no monthly fees admisnistrasi. b) Both of them have different aspects deposit base, 
opening of accounts, administrative costs account opening, the initial deposit, disbursement / withdrawal of savings, guarantees by LPS, account closing fees, online registration SISKOHAT, profit sharing, and the ability of the results in to cover annual inflation rates $\mathrm{ONH}$. 


\section{References}

A. Karim, Adiwarman. (2009). Bank Islam: Analisis Fiqih dan Keuangan. Jakarta: PT. Raja Grafindo Persada.

(2004). Ekonomi Makro Islami. Jakarta: PT. Raja Grafindo Persada.

Al-Arabi, Ibn. (t.th). Ahkam al-Qur'an. Beirut: Dar al-Ma'rifah.

Al-Kramly, Anestas. (1987). al-Nuqu'd al-Arabiyah wa al-Islamiyah wa IImu al-Nammiyat. t.t: alMarkaz al-Islamy Li Thiba'ah wa al-Nasyr.

Al-Naqsyabandi, Nashir al-Sayyid Mahmud. (1969). al-Dirham al-Islami al-Madhru>b 'Ala alThira>z al-Sa'sa'ni. Baghdad: al-Majma al-IImi al-Iraqi.

Al-Fayu'mi, Ahmad. (1926). al-Misba'h al-Munir fi Gharib al-Syarh al-Kabir li al rafi',.. Kairo: alMathba'ah al-Amiriyah.

Al-Mishri, Rafiq. (1987). Lamahat 'an al-Nuqud fi al-Islam, dalam Qira'at fi al Iqtishad al-Islami. Jeddah: Markaz al-Nasyr al-'llmi.

Ali al-Maqrizi, Taqiyuddin Ahmad bin. Ighats al-Ummah bi Kasyf al-Gummah. Hams : Dar Ibn alWahid.

an-Nabhani, Taqiyuddin. (2009). Sistem Ekonomi Islam, Terjemahan oleh Redaksi al-Azhar Press. Bogor: al-Azhar Press.

Antonio, Muhammad Syafi'i. (2009). Bank Syariah Dari Teori Ke Praktik. Jakarta : Gema Insani Press.

Arikunto, Suharsimi. (2002). Prosedur Penelitian Suatu Pendekatan Praktek. Jakarta: Rineka Cipta.

Az. Nasution. (2002). Hukum Perlindungan Konsumen: Suatu Pengantar. Jakarta: Diadit Media.

Dewan Syari'ah Nasional, Himpunan Fatwa Dewan Syari'ah Nasional Untuk Lembaga Keuangan Syari'ah, Ed. 1, Diterbitkan atas Kerjasama Dewan Syari'ah Nasional-MUI dengan Bank Indinesia, (2001), hlm. 87

Dirjen Penyelenggara Haji dan Umrah. (2012) Retrivied Februari 27, 2012 from www.kemenag.go.id.

Falah, Syamsul, Pola Bagi Hasil pada Perbankan Syari'ah, Makalah disampaikan pada seminar ekonomi Islam, Jakarta, 20 Agustus 2003.

Iqbal, Muhaimin, (2011) "Dinar Untuk Perencanaan Haji Lebih Murah Lebih Nyaman," Gerai Dinar. Retrivied March 2, 2012 from , http://dinartauhid.com/2011/05/dinar-untuk-perencanaanhaji-lebih-murah-lebih nyaman $\% \mathrm{e} 2 \% 80 \% a 6 /$ 
(2012). Menabung Dinar Menjadi Semakin Mudah Dengan M-Dinar Saving Account. http://www.geraidinar.com.

(2012). Cara Buka Rekening M-Dinar. http://dinaremasku.com.

Hakim, Atang Abdul. (2011). Fiqih Perbankan Syariah: Transformasi Fiqih Muamalah ke dalam Peraturan Perundang-Undangan. Bandung: Refika Aditama.

Hamidi, M. Luthfi. (2007). Gold Dinar: Sistem Moneter Global Yang Stabil dan Berkeadilan. Jakarta: Senayan Abadi Publishing.

Hasan, Ahmad. (2005). Mata Uang Islami: Telaah Komprehensif Sistem Keuangan Islam, Terjemah Saifurrahman Barito dan Zulfakar Ali. Jakarta: PT. RajaGrafindo Persada.

Hermawan, Asep. (2006). Penelitian Bisnis Paradigma Kualitatif. Jakarta : PT. Gramedia Widia Sarana Indonesia.

Himpunan Fatwa DSN-Majelis Ulama Indonesia, Edisi ke-2, tahun 2003.

Ibnu Qayyim. (1977). I'lam al-Muwaqqi'in, tahqiq oleh Muhammad Muhyi al-Dn 'Abd al-Haidar. Beirut: Dar al-Fikr.

Indonesia (a) Undang-Undang Perlindungan Konsumen, Undang-undang Nomor 8 Tahun 1999 Lembaran Negara 42 tahun 1999 Tambahan Lembaran Negara nomor 3821, penjelasan Psl. 5

Khalwaty, Tajul. (2000). Inflasi Dan Solusinya. Jakarta : PT. Gramedia Pustaka Utama.

Manullang, M. (1993). Ekonomi Moneter. Jakarta : Ghalia Indonesia.

Majelis Ulama Indonesia, Dewan Syariah nasional. Fatwa Dewan Syariah Nasional Majelis Ulama Indonesia, No 02/DSN-MUI/IV/2000 tentang Tabungan.

Muhammad. (2005). Manajemen Bank Syariah. Yogyakarta : UPP AMP YKPN.

Mulyadi. (2005). Akuntansi Biaya. Yogyakarta: STIE YKPN

Sukirno, Sadono. (2002). Pengantar Teori Makroekonomi. Jakarta: PT Raja Grafindo Persada.

Saifullah, A. (2009). Uang Kertas VS Dinar dan Dirham Islam. Bogor: Pustaka Thariqul Izzah.

Sumarwan, Ujang. (2004). Perilaku Konsumen: Teori Dan Penerapannya Dalam Pemasaran. Bogor: Ghalia Indonesia.

Sutisna, (2003). Perilaku Konsumen Dan Komunikasi Pemasaran. Bandung: PT. Remaja Rosdakarya.

Sugiyono. (2006). Metode Penelitian Kuantitatif, Kualitatif dan R \& D. Bandung: Alfabeta. (2009). Memahami Penelitian Kualitatif. Bandung : Alfabeta. 
(2007). Metode Penelitian Bisnis. Bandung: Alfabeta.

Sukmalinto, Pengelola/Owner Dinar Tauhid Bandung, Wawancara Mendalam, Bandung, 5 Juni 2012.

Shomad, Abdul. (2011). "Mudharabah, Dapat Ditarik setiap Saat," Surabaya Pagi, Retrivied March 01, 2012.

Tim Pengembangan Perbankan Syariah Institut ankir Indonesia, Konsep, Produk, hlm. 264

Tim Pengembangan Perbankan Syariah IBI, Konsep, Produk dan Implementasi Operasional Bank Syafi'i, Muhammad Zaki. (1982). Muqaddimah fi al-Nuqud wa al-Bunuk. t.t: Da'r al-Nahdhah al-Arabiya.

Usman, Husaini dan R. Purnomo. (2008). Pengantar Statistika. Jakarta : PT. Bumi Aksara.

Wajdi, Muhammad Farid. (t.th). Daira't Ma'arif al-Qarni al-'Isyrin. Beirut: Da'r al-Ma'rifah.

Wiroso. (2005). Penghimpunan Dana dan Distribusi Hasil Usaha Bank Syariah. Jakarta: Grasindo.

Wajdi, Muhammad Farid. (No. Year). Dairat Ma'arif al-Qarni al-'Isyrin. Beirut: Dar al-Ma'rifah.

Widjaja, Gunawan. (2000). Hukum Tentang Perlindungan Konsumen. Jakarta: PT Gramedia Pustaka Utama.

Yasri. (1988). Dirasat fi ‘llm al-lqtishad al-Islami. Iskandariyah: Dar al-Jami’at al-Mishriyah. 